Research Article

\title{
Conceptualization Approach for Accessibility-Aware Framework
}

\author{
Saqib Ali, Taiseera Al Balushi and Ali Al-Badi \\ Department of Information Systems, College of Economics and Political Science Sultan Qaboos \\ University, Al-Khoudh, Muscat, Sultanate of Oman
}

Correspondence should be addressed to: Saqib Ali; saqib@squ.edu.om

Received 29 August 2012; Accepted 25 September 2012; Published 25 June 2013

Academic Editor: Woo Kok Hoong

Copyright (C) 2013 Saqib Ali, Taiseera Al Balushi and Ali Al-Badi. Distributed under Creative Commons CC-BY 3.0

\begin{abstract}
For many people, the use of the technology offers opportunities to engage in activities that would otherwise be impossible. However, this potential can only be realised if the technology is designed so that it can support people in achieving their goals. Information access for people with special needs is creating numerous opportunities and challenges within the Information expressway community. A majority of web based information and services are inaccessible to people with certain disabilities, largely due to a lack of awareness of accessibility issues on the part of composers and developers in web engineering. There are many factors that contribute to achieving designs for accessibility, but one important issue is the availability of knowledge about how to design solutions that will take into account users and their diverse characteristics.

This research discusses the need for a framework approach to determine the level of accessibility required by people with special needs to access web resources, the results of such an approach should be as meaningful as possible for web applications developers and composers. It is also argued that the current accessibility evaluation approaches are unsatisfactory in the scope and results presentation. This research will outline the groundwork for constructing accessibility aware framework approach where people with distinct needs can access all web applications based on their level of disability. The approach provides guidelines for web developers and composers in the development of accessible web solutions. Blindness and Deafness disability profiles are used as an example to demonstrate the execution of the framework approach and presented implementation architecture.
\end{abstract}

Keywords: Accessibility, Accessible web applications, User generated content, W3C, WCAG, EARL, Semantic web, Disability section 508.

\section{Introduction}

The web offers so many opportunities for people with special needs that are unavailable through any other medium. It offers independence and freedom. However, if a website is not created with web accessibility in mind, it may exclude a segment of the population that stands to gain the most from the Internet. Web accessibility is the ongoing process of helping web authors ensure that members of the disabled community are able to gain access to the same electronic information

Cite this Article as: Saqib Ali, Taiseera Al Balushi and Ali Al-Badi (2013), "Conceptualization Approach for Accessibility-Aware Framework," Communications of the IBIMA, Vol. 2013 (2013), Article ID 477923, DOI: 10.5171/2013.477923 
or content as non-disabled individuals. Making web content accessible is a matter of incorporating basic accessibility features into the overall design process. Many web authors need to be aware of web accessibility issues. In addition, technologies such as Flash, Portable Document Format (PDF), and dynamic sites have created new barriers of entry.

Accessibility is a general term used to describe the degree to which a product, device, service, or environment is available to everyone as possible. Accessibility can be viewed as the "ability to access" and benefit from some systems or entities. Accessibility is used to focus on people with special needs and their right of access to entities, often through use of assistive technology.

The term accessible design is used to refer to design intended to maximize the number of potential customers who can readily use a website. Accessible design can impact market size and market share through consideration of the functional needs of all consumers, including those who experience functional limitations as a result of ageing or disabling conditions. A functional limitation describes a reduced sensory, cognitive, or motor capability associated with human ageing, temporary injury, or permanent disability that prevents a person from communicating, working, playing, or simply functioning in an environment where other people in the population can function (Monterey Technologies Inc, 1996).

Web accessibility refers to the degree to which web information is accessible to all human beings (e.g. disabled, able-bodied, old and young). That is, the goal of web accessibility is to allow universal access to information on the web by all people but especially by people with special needs. In addition, the information must be accessible by automatic machine tools (e.g. site indexing tools, robots etc.).

Web technologies have evolved over time from Web 1.0 (static web pages) to Web 1.5 (CMS oriented website) to Web 2.0 which are fully responsive web applications that mimic desktop programs - and also allow users to store and share information across the network (adactio.com, 2005). The term Web 2.0 can be defined as intersection of web application features that facilitate participatory information sharing, interoperability and collaboration on the World Wide Web.

Web 2.0 is the next version of websites, which is more attractive, simple, usable, scalable, bright and sharable by designing it with web 2.0 standards. Web 2.0 is not only changing the web design concept it's also changing the web marketing concepts, programming concepts, and usability concepts (Magazine, 2007). A Web 2.0 site allows users to interact and collaborate with each other in a social media dialogue as creators of user-generated content in a virtual community, in contrast to websites where users are limited to the passive viewing of content that was created for them. Web 2.0 can be described into three main parts: 1) RIA (Rich Internet Application) where web application or website give a feel of desktop application with high usability and graphics; 2) SOA (Service Oriented Architecture) where websites acts as services to users or to another websites e.g. RSS; 3) Web services and social web where there is high interaction of website with users, making the end-users an integral part of it.

Web 2.0 made new services possible due to new abilities of websites to share and aggregate data, and for users to be able to participate in managing and authoring web content. Web 2.0 will be used to bring a host of new services implementing day-today activities such as banking, shopping, gaming, entertainment etc. Creating avenues for future growth; bring more cost effectiveness and more convenience for many people; however, it might have adverse impact on people with special needs. However, web brings accessibility benefits such as use of "mashups" by community to enhance accessibility, provide dynamic help that suites user experience with preferences and web 2.0 in conjunction with semantic web is likely to help more accessible websites. Examples of Web 2.0 websites includes social 
networking sites, blogs, wikis, video sharing sites, hosted services, web applications, mashups, folksonomies etc.

Web 2.0 showed a new understanding of the Internet which allowed the sharing of information for all people using a platform. The expansion of Web 2.0 to Web 3.0 (semantic web) is already the evolving new era of internet technology. Web 3.0 uses semantics as an intelligent connecting links in order to allow relationships between content, authors, services and users. It gives power to the users to get more information about authors or topic when it is required.

We are living in the world of Web 3.0, where hundreds of millions of people are connected to the Internet and millions of those people are connected on social networking sites like Facebook, LinkedIn, MySpace, and Twitter, using blogs, and posting on YouTube and Flickr. The vast amount of ways in which people can be connected online has sparked the interest of cloud computing services. Cloud computing services have been developing ways to tap into the Web 3.0 world and establish means of turning the flow of information and communication into business potential.

Although substantial energy has been put into defining the business case and value for cloud computing, adopting and implementing it, very little focus has been given to ensuring the accessibility of cloud computing models. W3C's Web Content Accessibility Guideline (WCAG) will ensure accessibility of cloud services; however, those guidelines apply to web-based access only. Additional thoughts and planning are required for the inclusion of assistive technologies as part of the "Software as a Services"; services can be enhanced to more broadly meet the needs of all users.

This research presents a fundamental understanding about accessibility, accessibility standards and guidelines analysis with challenges and limitation followed by accessibility issues with Web
2.0 and beyond web applications. At the end, we present an accessibility aware framework approach with system architecture followed by conclusion.

\section{Analytical View of Accessibility Standards and Guidelines}

There are numerous efforts in providing guidelines and measurements for web 2.0 accessibility. The main area of focus is social media (huge user generated contents) and Rich Interactive Application which make use of AJAX. W3C developed number of standards and guidelines for the purpose of standardization and accessibility such standards includes Authoring Tool Accessibility Guidelines (ATAG) (W3C, 2011a), Accessible Rich Internet Application Suite (WAI-ARIA) (W3C, 2011c), Evaluation and Report Language (EARL) (W3C, 2011b), User Agent Accessibility Guidelines (UAAG) (W3C, 2005) and Web Content Accessibility Guidelines (WCAG) (W3C, 2011d). Table 1, presents an analysis of different frameworks with their areas of focus, technology/tools used, principles, guidelines and challenges. 
Table 1: General Web Accessibility Guidelines Analysis

\begin{tabular}{|c|c|c|c|c|}
\hline Frameworks & Area Focus & $\begin{array}{l}\text { Technology / } \\
\text { Tools }\end{array}$ & $\begin{array}{l}\text { Principles and } \\
\text { Guidelines }\end{array}$ & Challenges / Limitations \\
\hline $\begin{array}{c}\text { ATAG 2.0 } \\
(\mathrm{W} 3 \mathrm{C}, 2011 \mathrm{a})\end{array}$ & $\begin{array}{l}\text { Developers - } \\
\text { authoring } \\
\text { tools } \\
\text { (software that } \\
\text { creates } \\
\text { websites) }\end{array}$ & $\begin{array}{l}\text {-HTML } \\
\text {-XML } \\
\text {-Word } \\
\text { processors } \\
\text {-Multimedia } \\
\text { tools } \\
\text {-Content } \\
\text { management } \\
\text { Systems (CMS) } \\
\text {-CSS formatting } \\
\text { tools e.g. blogs, } \\
\text { wikis, photo } \\
\text { sharing sites, } \\
\text { and social - } \\
\text { networking sites. }\end{array}$ & $\begin{array}{l}\text { - } 28 \text { check points } \\
\text { - Producing accessible } \\
\text { output } \\
\text { - Prompting user for } \\
\text { accessibility related } \\
\text { information } \\
\text { - Checking inaccessible } \\
\text { content } \\
\text { - Integrating } \\
\text { accessibility in the } \\
\text { overall "look and feel", } \\
\text { help and documentation } \\
\text { - Make the authoring } \\
\text { tool accessible to people } \\
\text { with special needs. }\end{array}$ & $\begin{array}{l}\text { - Currently no web authoring tools } \\
\text { that support all accessible design } \\
\text { techniques exclusively from the } \\
\text { graphic user interface (AccessIT, } \\
\text { 2005). } \\
\text { - Tools meant to improve } \\
\text { accessibility cannot themselves be } \\
\text { inaccessible (Clark, 2004). } \\
\text { - Many of the ATAG techniques are } \\
\text { vastly overblown and unworkable } \\
\text { (Clark, 2006). }\end{array}$ \\
\hline $\begin{array}{c}\text { WAI-ARIA } \\
\text { (W3C, 2011c) }\end{array}$ & $\begin{array}{l}\text { Developers - } \\
\text { web } \\
\text { applications } \\
\text { (dynamic web } \\
\text { content } \\
\text { applications) }\end{array}$ & $\begin{array}{l}\text {-AJAX } \\
\text {-DHTML } \\
\text {-JavaScript } \\
\text {-HTML5 } \\
\text {-Other web } \\
\text { related } \\
\text { technologies }\end{array}$ & $\begin{array}{l}\text { - Framework for adding } \\
\text { attributes to identify } \\
\text { features for user } \\
\text { interaction } \\
\text { - Navigation techniques } \\
\text { to mark regions and } \\
\text { common web structures. } \\
\text { - Technologies to map } \\
\text { controls and AJAX live } \\
\text { regions } \\
\text { - Custom control events } \\
\text { to accessibility } \\
\text { application programming } \\
\text { interfaces (APIs) }\end{array}$ & $\begin{array}{l}\text { - Aria roles and properties not } \\
\text { available in new language version } \\
\text { e.g. HTML5 (Faulkner, 2010). } \\
\text { - WAI-ARIA defines a set of rules } \\
\text { for mapping roles, states and } \\
\text { properties to an accessibility API, } \\
\text { and does not define any } \\
\text { functionality (Everett, 2011). } \\
\text { - WAI-ARIA's lack of robustness is } \\
\text { another problem: Its } \\
\text { implementation in browsers and } \\
\text { assistive technology is not that } \\
\text { stable yet (Fischer, 2010). }\end{array}$ \\
\hline $\begin{array}{c}\text { EARL } \\
\text { (W3C, 2011b) }\end{array}$ & $\begin{array}{l}\text { Developers - } \\
\text { Expression of } \\
\text { website } \\
\text { evaluation } \\
\text { test results in } \\
\text { a vendor- } \\
\text { neutral and } \\
\text { platform } \\
\text { independent } \\
\text { format }\end{array}$ & $\begin{array}{l}\text {-Web } \\
\text { accessibility } \\
\text { evaluation tools } \\
\text {-Web quality } \\
\text { assurance and } \\
\text { validation tools } \\
\text {-Web authoring } \\
\text { and } \\
\text { development } \\
\text { tools } \\
\text {-Web content } \\
\text { description and } \\
\text { labeling } \\
\text { frameworks. }\end{array}$ & $\begin{array}{l}\text { - Resource Description } \\
\text { Framework (RDF) is } \\
\text { used to define the terms } \\
\text { of expressing test results. } \\
\text { - The main components } \\
\text { are assertor, test subject, } \\
\text { test criterion and test } \\
\text { result } \\
\text { - Support use cases such } \\
\text { as combining results } \\
\text { from software tools, } \\
\text { exchanging data between } \\
\text { software tools, querying } \\
\text { and analyzing test } \\
\text { reports, benchmarking } \\
\text { software testing tools, } \\
\text { evaluating dynamic and } \\
\text { multilingual websites } \\
\text { and annotating web } \\
\text { resources with metadata. }\end{array}$ & $\begin{array}{l}\text { - EARL descriptions will be RDF } \\
\text { expressions but deciphering } \\
\text { metadata in RDF that is well- } \\
\text { formed with clear parsing rules } \\
\text { should not present a problem in a } \\
\text { DC environment (Nevile, 2010). } \\
\text { - One of the issues includes } \\
\text { describing the occurrence of test } \\
\text { results (for example accessibility } \\
\text { violations) within a website } \\
\text { (Abou-Zahra, 2006). } \\
\text { - How can EARL reports be more } \\
\text { resilient towards changes made on } \\
\text { an already evaluated website? } \\
\text { (Abou-Zahra, 2006). }\end{array}$ \\
\hline $\begin{array}{c}\text { UAAG } \\
(\mathrm{W} 3 \mathrm{C}, 2005)\end{array}$ & $\begin{array}{l}\text { Developers of } \\
\text { user agents }\end{array}$ & $\begin{array}{l}\text {-Web browsers } \\
\text {-Media players } \\
\text {-Assistive } \\
\text { technologies }\end{array}$ & $\begin{array}{l}\text { - } 12 \text { guidelines include } \\
\text { number, title, guidelines } \\
\text { addresses, rational } \\
\text { behind the guideline and } \\
\text { check points. } \\
\text { - Comprehensive set of } \\
\text { check points cover access } \\
\text { to all content, user } \\
\text { control over content, } \\
\text { user control over user } \\
\text { interface and standard } \\
\text { programming interfaces. }\end{array}$ & $\begin{array}{l}\text { - No web browser currently fully } \\
\text { supports UAAG. It can be very } \\
\text { costly to upgrade to better } \\
\text { browsers across an institution } \\
\text { (staff, 2011). }\end{array}$ \\
\hline
\end{tabular}




\begin{tabular}{|c|c|c|c|c|}
\hline $\begin{array}{c}\text { WCAG } \\
(\mathrm{W} 3 \mathrm{C}, 2011 \mathrm{~d})\end{array}$ & $\begin{array}{l}\text { Developers of } \\
\text { web content } \\
\text { (webpage, } \\
\text { web } \\
\text { application, } \\
\text { including text, } \\
\text { images, forms, } \\
\text { sounds, and } \\
\text { such) }\end{array}$ & $\begin{array}{l}\text {-Web content } \\
\text {-Web authoring } \\
\text { tool } \\
\text {-Web } \\
\text { accessibility } \\
\text { evaluation tool } \\
\text {-Technical } \\
\text { standard for web } \\
\text { accessibility }\end{array}$ & $\begin{array}{l}\text { - } 4 \text { Principles } \\
\text { perceivable, operable, } \\
\text { understandable, and } \\
\text { robust. } \\
\text { - } 12 \text { Guidelines. } \\
\text { - Each guideline have } \\
\text { testable success criteria } \\
\text { - Three levels of } \\
\text { conformance are defined } \\
\text { as: A (lowest), AA, and } \\
\text { AAA (highest). }\end{array}$ & $\begin{array}{l}\text { - Guidelines are extremely vague, } \\
\text { language complexity, definition } \\
\text { very hard to understand, poor } \\
\text { usability, very long document } \\
\text { (www.webcredible.co.uk, 2011) } \\
\text { - When compared to the intuitive } \\
\text { notion of accessibility, perhaps the } \\
\text { main limitation of the WCAG } 2.0 \text { is } \\
\text { the relatively modest support for } \\
\text { evaluating cognitive accessibility } \\
\text { (Nykänen, 2012). }\end{array}$ \\
\hline $\begin{array}{c}\text { Progressive } \\
\text { enhancement } \\
\text { with AJAX } \\
\text { (adactio.com, } \\
\text { 2005) }\end{array}$ & $\begin{array}{l}\text { Developers of } \\
\text { website / web } \\
\text { application }\end{array}$ & $\begin{array}{l}\text {-HTML } \\
\text {-PHP } \\
\text {-CSS } \\
\text {-AJAX } \\
\text {-JavaScript }\end{array}$ & $\begin{array}{l}\text { - Develop a website for } \\
\text { JavaScript disabled } \\
\text { clients/users. } \\
\text { - Enhance a website for } \\
\text { JavaScript enabled } \\
\text { clients/users. } \\
\text { - Technique termed as } \\
\text { "Hijax". }\end{array}$ & $\begin{array}{l}\text { - Major weakness: when } \\
\text { JavaScript is enabled, there is no } \\
\text { way to link directly to a particular } \\
\text { set of data (like you would be able } \\
\text { to do with the PHP-only version) } \\
\text { (Lazaris, 2009). } \\
\text { - There are still good reasons to } \\
\text { keep using progressive } \\
\text { enhancement, but it may be time to } \\
\text { accept that JavaScript is an } \\
\text { essential technology on today's } \\
\text { web, and stop trying to make } \\
\text { everything work in its absence } \\
\text { (Morgan, 2011). } \\
\text { - It's working pretty nicely but it's } \\
\text { not without its problems, namely } \\
\text { accessibility issues. When a } \\
\text { portion of the page is updated, } \\
\text { there's nothing to indicate that to a } \\
\text { screen reader (Almaer, 2005). }\end{array}$ \\
\hline $\begin{array}{c}\text { Others } \\
\text { web2access.org } \\
\text {.uk, PAS 78/BS } \\
\text { 8878:2010, UK } \\
\text { Government's } \\
\text { e-Accessibility } \\
\text { action plan }\end{array}$ & $\begin{array}{l}\text { Developers of } \\
\text { accessible } \\
\text { websites and } \\
\text { web-based } \\
\text { application }\end{array}$ & $\begin{array}{l}\text {-Websites } \\
\text {-Web browser } \\
\text {-Web services } \\
\text {-Web-based } \\
\text { applications }\end{array}$ & $\begin{array}{l}\text { - Provides a set of good } \\
\text { accessibility test results } \\
\text { - Outline a framework } \\
\text { for web accessibility } \\
\text { when designing or } \\
\text { commissioning web } \\
\text { products } \\
\text { - Web accessibility code } \\
\text { of practice. }\end{array}$ & $\begin{array}{l}\text { - Practically impossible to design a } \\
\text { site that will comply with the UK } \\
\text { DDA as the UK DDA does not refer } \\
\text { to WCAG and it does not lay down } \\
\text { a specific level of accessibility for } \\
\text { all websites (Anderson, 2010). } \\
\text { - BS } 8878 \text { covers 'Web products' } \\
\text { and not just websites however the } \\
\text { code of practice doesn't cover } \\
\text { software (Kelly, 2010). }\end{array}$ \\
\hline
\end{tabular}

Regardless of what type of disabled users accessing website contents, it is very important that content generated by end users in Web 2.0 should also confirm to accessibility standards. Considering the fact that user is the main entity in generating contents in any web 2.0 website, ATAG provides guidelines for designing web content authoring tools that are both more accessible to authors with special needs and designed to enable, support, and promote the production of accessible web content by all authors (W3C, 2011a).

The Authoring Tool Accessibility Guidelines 2.0 (ATAG 2.0) is part of a series of accessibility guidelines published by the W3C Web Accessibility Initiative (WAI) (W3C, 2011a).
WAI-ARIA defines a way to make web content and web applications more accessible to people with special needs. It especially helps with dynamic content and advanced user interface controls developed with AJAX, HTML, JavaScript, and related technologies (W3C, 2011c).

Many web applications are using advanced and complex user controls (tree view, drag and drop etc.) to provide rich user experience. But features of these controls are not accessible to users with disabilities special needs as they are not properly interpreted by Assistive Technologies (AT). 
WAI-ARIA addresses these accessibility challenges by defining how information about this functionality can be provided to assistive technology. With WAI-ARIA, an advanced web application can be made accessible and usable to people with special needs. WAI-ARIA provides a framework for adding more attributes (roles and properties) to identify features of complex and advanced controls by assistive technology. WAI-ARIA acts like a contract between the assistive technology and application to enable access to rich content with the semantic information necessary to make the content accessible.

The Evaluation and Report Language (EARL) is a machine-readable format for expressing test results (W3C, 2011b). The primary motivation for developing EARL is to facilitate the processing of test results, such as those generated by: web accessibility evaluation tools, web quality assurance and validation tools, web authoring and development tools and web content description and labelling frameworks.

Web authoring tools and quality assurance software can use EARL to aggregate test results obtained from different testing tools including web accessibility evaluation tools, validators, and other types of content checkers. EARL uses the Resource Description Framework (RDF) to define the terms for expressing test results. The basic idea of EARL is to report test results as machine process-able statements.

The User Agent Accessibility Guidelines (UAAG) explains how to make user agents accessible to people with special needs, particularly to increase accessibility to web content. User agents include web browsers, media players, and assistive technologies, which are software that some people with special needs use in interacting with computers (W3C, 2005). UAAG is primarily for developers of web browsers, media players, assistive technologies, and other user agents.

UAAG 1.0 (Jacobs, Gunderson, and Hansen, 2002) provides guidelines for designing user agents that lower barriers to web accessibility for people with special needs (visual, hearing, physical, cognitive, and neurological). UAAG are also intended to meet the needs of many different audiences, including policy makers, managers, and others. For example: people who want to choose user agents that are more accessible can use UAAG to evaluate user agents, people who want to encourage their existing user agent developer to improve accessibility in future versions can refer the user agent vendor to UAAG.

The individuals and organizations that use WCAG vary widely and include web designers and developers, policy makers, purchasing agents, teachers, and students. In order to meet the varying needs of this audience, several layers of guidance are provided including overall principles, general guidelines, testable success criteria and a rich collection of sufficient techniques, advisory techniques, and documented common failures with examples (W3C, 2011d).

WCAG 2.0 has twelve guidelines that are organized under four principles: perceivable, operable, understandable, and robust. For each guideline, there are testable success criteria, which are at three levels: A, AA, and AAA.

This progressive enhancement with AJAX technique is provided to build web application for clients with disabled or no JavaScript. As AJAX is completely based on JavaScript, disabling it will make the web application non-functional or inaccessible. To avoid this situation many websites will have a non-JavaScript version which is separately developed consuming more time and resources. But following progressive enhancement for AJAX technique developers can develop a website both for JavaScript enabled and disabled users.

Web2Access in UK (Web2Access.org.uk, 2012) provides a set of good accessibility test results for various disabilities according to PAS 78 (Guide to good practice in commissioning accessible websites). However, PAS 78 is converted to BS 8878 (BS 8878: 2010 - web 
accessibility code of practice). BS 8878:2010 is the first British standard to outline a framework for web accessibility when designing or commissioning web products. It provides guidance for all sectors on meeting the requirements of the Equality Act 2010 (HomeOffice, 2011), which states that web products must be accessible to all. The BS 8878:2010 code of practice applies to all products delivered via a web browser, including websites, web services and web-based applications such as email. The standard also focuses on processes rather than technical or design issues and is recognized by the UK Government's e-Accessibility action plan (dcms, 2011) as a key tool for developing accessible online services. There is ongoing work for an accessible twitter named as 'easy chirp' (easychirp.com, 2011). Easy Chirp is a web-accessible alternative to the twitter.com website. It is designed to be easier to use and is optimized for disabled users. It also works with keyboard-only, older browsers like IE6, low band internet connection, and without JavaScript.

\section{Accessibility Issues with Web 2.0 and Beyond Websites}

Accessibility of websites is becoming very important in general and in particular for e-Government. Introduction of Web 2.0 and beyond make more important to review the accessibility of websites. Specially with the massive growth of Web 2.0 based applications due to the richness of graphical user interfaces, effects, high interactivity and collective intelligence of potential that Web 2.0 based applications can provide (Kern, 2008).

Cooper stated that with Web 2.0 there are several challenges, such as: ongoing evolution of technology; accessibility techniques fall behind due to the speed at which the new approaches emerge, interactive technologies are more difficult than static content and increased need for accessibility expertise where specialists must understand the technology behind interactive or aggregate content in order to pose meaningful accessibility solutions (Cooper, 2007).
There are a number of accessibility issues with Web 2.0 applications that can cause problems for disabled web users. AJAX has major share in issues related to disabled users when it comes to web 2.0. Some of the known issues are highlighted by (Moonan, 2007) as: inaccessible WYSIWYG editors and inaccessible interfaces which are dependent on drag and drop. The other challenges include screen reader users are not alerted when content has changed dynamically using Ajax (www.webaim.org, 2012) and rich media is included without captions or alternatives (Crichton, 2007). Also users not being forced to a accessibility issues when inputting content and inaccessible controls on audio or video players that are not compatible with assistive technologies.

It is not easy to tackle the accessibility issue for disabled users in Web 2.0 due to huge generation of end users content (M Cha, 2007). One of the important issues identified is related to AJAX which is highly used in Web 2.0 followed by CSS. AJAX is used to increased usability and interactivity but accessibility is ignored somehow.

\section{Accessibility-Aware Framework Approach}

This section presents an accessibility aware framework approach which will be used to cater accessibility for all including people with special needs.

The proposed approach will especially help developer's community to overcome several current challenges they face during the development life cycle of accessible websites. The main objective is to provide developer's community a single window shop concept to follow during the accessible website development process in order to reduce the development timelines and make it cost effective. It is technology platform independent; developer may choose any scripting language which can accommodate accessibility aware framework guidelines. Figure 1 depicted the overview of the proposed novel accessibility-aware framework approach. 


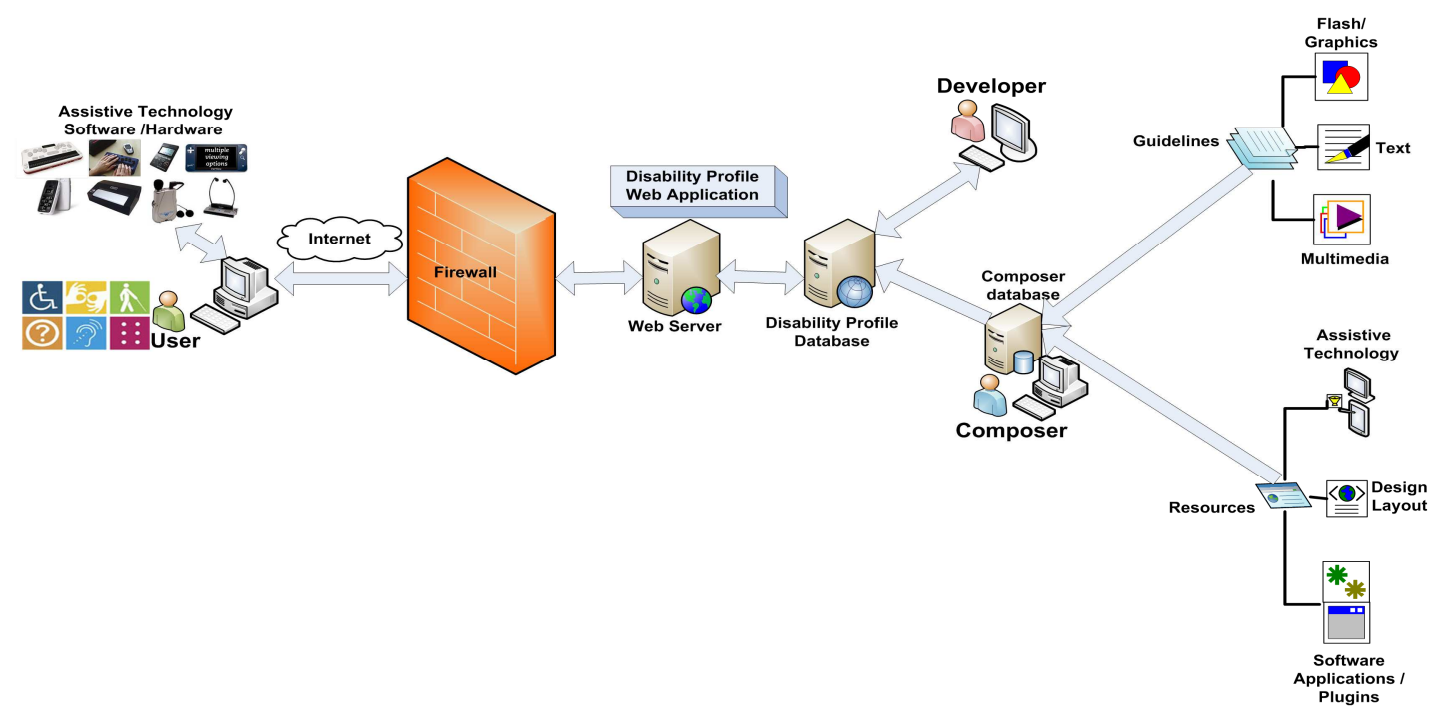

Figure 1: Accessibility-Aware Framework Approach

\section{Components of the Proposed Framework}

This framework approach is further divided into five different key components including user interface, web server, disability profile database, developer and composer components.

- User Interface: User: With any type of disability such as visual, hearing, motor and cognitive.

\section{Assistive Technology Software and} Hardware: Such as refreshable braille display, braille printers screen readers, screen magnifiers, noise reduction and amplification devices etc.

Internet: Internet connection to access web applications and services.

- Web Server: A server behind the firewall host the disability profile web application

Firewall: A firewall can either be software or hardware-based and is used to help keep a network secure. Disability Profile Web Application: This is a web application hosted on web server. It will be used as a door step and entertain all user side inbound and outbound http request via secure communication channel.
- Disability Profile Database: This is a content management server used by developer to design, develop, test and implement the disability profile web application.

- Developer Role: Design, develop, test and implement the disability profile web application based on input from composer.

- Composer: Compose detailed disability profile based on guidelines and resources.

Composer Database: Used by composer for disability profile composition work.

Guidelines: W3C and others web accessible guidelines/framework to make any type of website such as text, flash/graphics and multimedia.

Resources: Technical specification for assistive technology, design layout and software applications.

Composer will compose disability profile based on available guidelines and resources. Guidelines are very specific such as detail instruction on how to create text only accessible website, flash only accessible website, multimedia only accessible website or combination of all 
above accessible website. Resources will be used to provide technical specification on available assistive technology, software application and design layout for developer.

Composer will perform all his/her disability profile composition work on composer database server and once it is finalized it will be published and stored on disability profile database server (Content management server). Later developer will use this composed profile to cater their target audience e.g. blindness into their website.

Table 2 presents an example on blindness and hearing disability profile composition. It shows how the composer will compose the detail disability profile using guidelines and resources.

Table 2: Profile Composition Example for Disability Profile

\begin{tabular}{|c|c|c|}
\hline Description & Visual disability (Blindness) & Hearing impairments (Deafness) \\
\hline $\begin{array}{l}\text { Assistive } \\
\text { technology } \\
\text { software }\end{array}$ & - Screen readers & $\begin{array}{l}\text { - Captions - text with verbatim recording of any } \\
\text { speech and with descriptions of important } \\
\text { auditory information that appears } \\
\text { simultaneously with the audio (including audio } \\
\text { that accompanies video in multimedia). } \\
\text { - Transcripts - text manuscripts containing the } \\
\text { correct sequence of verbatim recording of any } \\
\text { speech, and descriptions of important auditory } \\
\text { or visual information. } \\
\text { - Sign language (Distinguishing and } \\
\text { understanding) }\end{array}$ \\
\hline $\begin{array}{l}\text { Assistive } \\
\text { technology } \\
\text { hardware }\end{array}$ & $\begin{array}{l}\text { - Speech synthesizer } \\
\text { - Braille and refreshable braille }\end{array}$ & Noise reduction and amplification hardware \\
\hline $\begin{array}{c}\text { Assistive } \\
\text { technology } \\
\text { browser }\end{array}$ & $\begin{array}{l}\text { - Text based browser (LYNX) } \\
\text { - Voice browser }\end{array}$ & Noise reduction and amplification hardware \\
\hline $\begin{array}{l}\text { Adaptive } \\
\text { strategies }\end{array}$ & - Tabbing through structural elements & No particular strategies defined \\
\hline $\begin{array}{c}\text { W3C } \\
\text { Guidelines } \\
\text { Principles }\end{array}$ & $\begin{array}{l}\text { - ATAG } 1.0 \text { - Guideline } 1 \text { - support accessible } \\
\text { authoring practices } \\
\text { - ATAG } 1.0 \text { - Guideline } 2 \text { - generate standard } \\
\text { markup } \\
\text { - ATAG } 1.0 \text { - Guideline } 3 \text { - support the creation } \\
\text { of accessible content } \\
\text { - ATAG } 1.0 \text { - Guideline } 4 \text { - provide ways of } \\
\text { checking and correcting inaccessible content } \\
\text { - ATAG } 1.0 \text { - Guideline } 5 \text { - integrate accessibility } \\
\text { solutions into the overall "look and feel" } \\
\text { - ATAG } 1.0 \text { - Guideline } 7 \text { - ensure that the } \\
\text { authoring tool is accessible to authors with } \\
\text { disabilities } \\
\text { - UAAG } 1.0 \text { - Guideline } 1 \text { - support input and } \\
\text { output device-independence } \\
\text { - UAAG } 1.0 \text { - Guideline } 10 \text { - orient the user } \\
\text { - UAAG } 1.0 \text { - Guideline } 11 \text { - allow configuration } \\
\text { and customization } \\
\text { - UAAG } 1.0 \text { - Guideline } 2 \text { - ensure user access to } \\
\text { all content } \\
\text { - UAAG } 1.0 \text { - Guideline } 3 \text { - allow configuration } \\
\text { not to render some content that may reduce } \\
\text { accessibility } \\
\text { - UAAG } 1.0 \text { - Guideline } 4 \text { - ensure user control of } \\
\text { rendering } \\
\text { - UAAG } 1.0 \text { - Guideline } 5 \text { - ensure user control of } \\
\text { user interface behavior } \\
\text { - UAAG } 1.0 \text { - Guideline } 6 \text { - implement }\end{array}$ & $\begin{array}{l}\text { - ATAG } 1.0 \text { - Guideline } 1 \text { - support accessible } \\
\text { authoring practices } \\
\text { - ATAG } 1.0 \text { - Guideline } 2 \text { - generate standard } \\
\text { markup } \\
\text { - ATAG } 1.0 \text { - Guideline } 3 \text { - support the creation } \\
\text { of accessible content } \\
\text { - ATAG } 1.0 \text { - Guideline } 7 \text { - ensure that the } \\
\text { authoring tool is accessible to authors with } \\
\text { disabilities } \\
\text { - UAAG } 1.0 \text { - Guideline } 11 \text { - allow configuration } \\
\text { and customization } \\
\text { - UAAG } 1.0 \text { - Guideline } 2 \text { - ensure user access to } \\
\text { all content } \\
\text { - UAAG } 1.0 \text { - Guideline } 3 \text { - allow configuration } \\
\text { not to render some content that may reduce } \\
\text { accessibility } \\
\text { - UAAG } 1.0 \text { - Guideline } 4 \text { - ensure user control of } \\
\text { rendering } \\
\text { - UAAG } 1.0 \text { - Guideline } 5 \text { - ensure user control of } \\
\text { user interface behavior } \\
\text { - WCAG } 2.0 \text { - Guideline } 1.1 \text { - text alternatives } \\
\text { - WCAG } 2.0 \text { - Guideline } 1.2 \text { - time-based media } \\
\text { - WCAG } 2.0 \text { - Guideline } 1.4 \text { - distinguishable } \\
\text { - WCAG } 2.0 \text { - Guideline } 3.1 \text { - readable }\end{array}$ \\
\hline
\end{tabular}


interoperable application programming interfaces

- UAAG 1.0 - Guideline 7 - observe operating environment conventions

- UAAG 1.0 - Guideline 8 - implement

specifications that benefit accessibility

- UAAG 1.0 - Guideline 9 - provide navigation

mechanisms

- WCAG 2.0 - Guideline 1.1 - text alternatives

- WCAG 2.0 - Guideline 1.2 - time-based media

- WCAG 2.0 - Guideline 1.3 - adaptable

- WCAG 2.0 - Guideline 1.4 - distinguishable

- WCAG 2.0 - Guideline 2.1 - keyboard accessible

- WCAG 2.0 - Guideline 2.4 - navigable

- WCAG 2.0 - Guideline 3.1 - readable

- WCAG 2.0 - Guideline 3.2 - predictable

- WCAG 2.0 - Guideline 4.1 - compatible

Developer will access disability profile composition from disability profile database server and apply into the disability profile web application development life cycle process. The disability profile web application will be hosted on web server behind firewall and ready for service.

User with any type of disability using assistive technology hardware and software will access the disability profile web application via internet.

\section{Three Tier System Architecture}

The system architecture is based on most widespread industry standards, the three tier architecture. The main benefit of three tier system architecture is that all business logic can be defined once within the application tier and then shared by any number of components within the presentation layer. Any changes to business rules can therefore be made in one place and be instantly available throughout the whole application. It also allows changing the contents of any one of tiers (layers) without having to make corresponding changes in any of the others. Other advantages include parallel development, easy to implement complex application rules and superior performance for medium to high volume environments. Figure 2 depicts how the proposed accessibility-aware framework approach can be implemented against any web application.

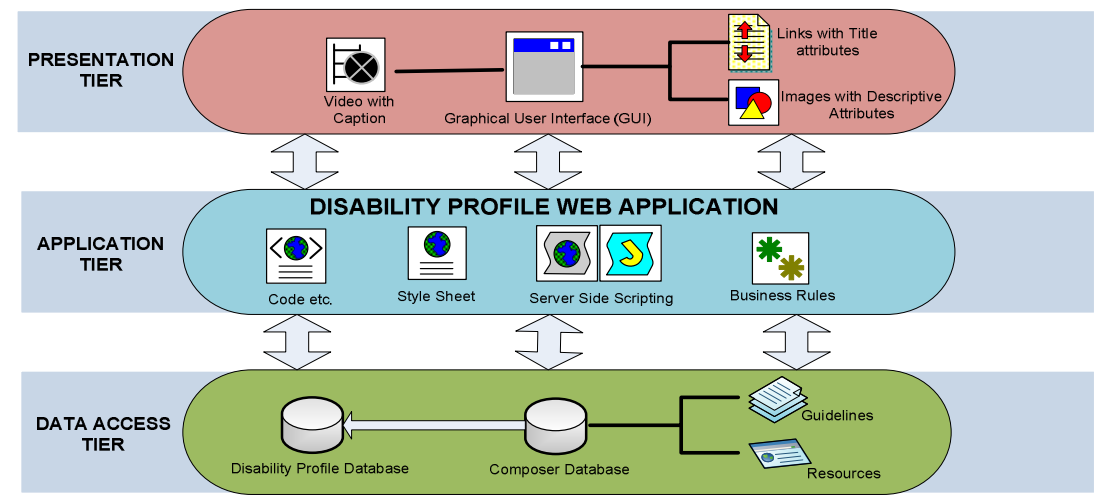

Figure 2: Three Tier System Architecture

- Presentation Tier: The top-most level of the application is the presentation tier which includes Graphical User Interface
GUI). The main function of the interface is to translate tasks and results to something the user can understand. 
- Application Tier: Application tier coordinates the disability profile web application, process commands, host business rules, make logical decisions and evaluations, and performs calculations. It also moves and processes data between the two surrounding layers.

- Data Access Tier: Data access tier includes composer database which is being used by composer to compose and store profiles based on type of disability using available guidelines and resources. Developer will than retrieve profiles and use in into the web application development life cycle.

Developer creates content and design layout by disability profile based on composer database and stores on disability profile database for disability profile web application. Composer composes the comprehensive disability profiles and stores on composer database. Disability profiles are created based on available guidelines and resources as shown in Table 2. At the user end, assistive technology hardware/software is integrated with web interface to assist the user with disability.

\section{Conclusion}

With the ever increasing use of computer and telecommunications technologies, there is a growing awareness of the need to ensure that websites and related web services are accessible to as many people as possible. The web is the most universal shared technology in common use today; however, access to the web and its many applications cannot be taken for granted. Web accessibility comprehends a variety of apprehensions ranging from societal, political, economic, physical and thorough to the purely technical. Thus, there are many perspectives from which web accessibility can be understood and assessed. This paper studied accessibility in general and web accessibility in specific. A number of accessibility frameworks and standards were analysed with regards to the area of focus, technology/tool used, guidelines provided, and their shortcomings.
In order to overcome these shortcomings of current web accessibility standards and guidelines, an accessibility aware framework approach is proposed using as its base layered framework. This framework can be used for developing accessible web applications and electronic services for people with special needs. This framework will serve as a toolkit for composer and developers "engraving" accessibility into emerging web applications. As part of future effort, the framework approach will be implemented and evaluated using blindness and deafness disability profiles.

\section{Acknowledgments}

The research leading to these results has received research project grant funding from the Research Council of the Sultanate of Oman Research Grant Agreement No [ORG SQU ICT 10 004].

\section{References}

Abou-Zahra, S. (2006). "Managing and Monitoring Website Accessibility," [Online], Accessed on 03/04/2012, [Available at: http://www.springerlink.com/content/33 66514453435qu3/]

AccessIT, University of Washington. (2005). Can I Make Accessible Web Pages Using Web Authoring Tools Such as FrontPage and Dreamweaver?. [Online], Accessed on 02/04/2012, [Available at:http://www.washington.edu/accessit/p rint.html?ID=1120]

Adactio.com. (2005). Progressive Enhancement with Ajax. [Online], Accessed on 25/03/2012, [Available at: http://adactio.com/journal/959/]

Almaer, D. (2005). Ajax Shopping Cart: Progressive Enhancement. [Online], Accessed on 03/04/2012, [Available at:http://ajaxian.com/archives/ajaxshopping-cart-progressive-enhancement]

Anderson, S. (2010). BS 88782010 Web Accessibility Code of Practice British Standard. [Online], Accessed on 
04/04/2012, [Available at:http://www.hobo-web.co.uk/bs8878/]

Cha, M., Kwak, H., Rodriguez, P., Ahn, Y. \& Moon, S. (2007). "I Tube, You Tube, Everybody Tubes: Analyzing the World's Largest User Generated Content Video System," In 'Proceedings of the 7th ACM SIGCOMM Conference on Internet Measurement. ACM pp. 1-14.

Clark, J. (2004). ATAG: Authoring Tool Accessibility Guidelines. [Online], Accessed on 02/04/2012, [Available at:http://joeclark.org/access/captioning/b poc/ATAG.html]

Clark, J. (2006). ATAG Assessment of WordPress. [Online], Accessed on 02/04/2012, [Available at: http://codex.wordpress.org/WordPress_A TAG_Evaluation]

Cooper, M. (2007). "Accessibility of Emerging Rich Web Technologies: Web 2.0 and the Semantic Web," In Proceedings of the 2007 International Cross-Disciplinary Conference on Web Accessibility (W4A) (W4A '07) New York, NY, USA.

Crichton, P. (2007). The Access 2.0 Interview - Liz Ball. [Online], Accessed on 06/12/2012, [Available at:http://www.bbc.co.uk/blogs/access20/ 2007/01/post_2.shtml]

dcms. (2011). The eAccessibility Action Plan: Making Digital Content Accessible by Everyone - June 2011. [Online], Accessed on 24/11/2011, [Available at:http://www.culture.gov.uk/publications /8375.aspx]

easychirp.com. (2011). Web Accessibility for the Twitter Website Application. [Online], Accessed on 24/01/2012, [Available at:http://www.easychirp.com/]

Everett. (2011). Are you Confused by HTML5 and WAI-ARIA Yet?. [Online], Accessed on 04/04/2012, [Available at:http://zufelt.ca/blog/are-you-confusedhtml5-and-wai-aria-yet]
Faulkner, S. (2010). HTML5 and the Myth of WAI-ARIA Redundance. [Online], Accessed on 03/04/2012, [Available at:http://www.paciellogroup.com/blog/20 10/04/html5-and-the-myth-of-wai-ariaredundance/]

Fischer, D. (2010). The Accessibility of WAI-ARIA. [Online], Accessed on 04/04/2012, [Available at:http://www.alistapart.com/articles/theaccessibility-of-wai-aria/]

HomeOffice. (2011). Equality Act 2010: Guidance. [Online], Accessed on 24/11/2011, [Available at: http://homeoffice.gov.uk/equalities/equali ty-act/]

Inc, Monterey Technologies. (1996). 'Resource Guideline for Accessible Design of Consumer Elements,'

Jacobs, I., Gunderson, J. \& Hansen, E. (2002). User Agent Accessibility Guidelines 1.0. [Online], Accessed on 17/12/2002, [Available at:http://citeseerx.ist.psu.edu/viewdoc/su mmary?doi=10.1.1.27.9433]

Kelly, B. (2010). BS 8878: "Accessibility has been Stuck in a Rut of Technical Guidelines" [Online], Accessed on 03/04/2012, [Available at:http://ukwebfocus.wordpress.com/201 0/12/09/bs8878-accessibility-has-beenstuck-in-a-rut-of-technical-guidelines/]

Kern, W. (2008). "Web 2.0 - End of Accessibility? Analysis of Most Common Problems with Web 2.0 Based Applications Regarding Web Accessibility," International Journal of Public Information Systems, 4 (2), 131-154.

Lazaris, L. (2009). Building an Ajax Application with Progressive Enhancement. [Online], Accessed on 02/04/2012, [Available at:http://www.impressivewebs.com/ajaxprogressive-enhancement/]

Magazine, Web 2.0. (2007). Your web 2.0 Guidelines. [Online],[Accessed on 21/03/2012], Available 
at:http://web2magazine.blogspot.com/200 7/01/your-web-20-guidelines.html

Mell, P. \& Grance, T. (2011). The NIST Definition of Cloud Computing. Gaithersburg, MD 20899-8930. USA: National Institute of Standards and Technology Special Publication 800-145. [Online], Accessed on 10/08/2011. [Available at:http://csrc.nist.gov/publications/nistpu bs/800-145/SP800-145.pdf.]

Moonan, K. (2007). Web 2.0 \& Accessibility for Disabled Users. [Online], Accessed on 24/01/2012, 2012, [Available at:http://ictknowledgebase.org.uk/web20a ndaccessibility]

Morgan, N. (2011). JavaScript and the End of Progressive Enhancement. [Online], Accessed on 01/04/2012, [Available at:http://skilldrick.co.uk/2011/05/javascr ipt-and-the-end-of-progressiveenhancement/]

Nevile, L. (2010). Why is Accessibility Metadata Proving Difficult? [Online], Accessed on 04/04/2012, [Available at:http://dublincore.org/groups/access/p oster.html\#e5]

Nykänen, O. (2012). Web Accessibility. [Online], Accessed on 04/04/2012, [Available

at:http://cirrie.buffalo.edu/encyclopedia/e n/article/310/]

O'Reilly, T. (2006). Web 2.0 Compact Definition: Trying Again. [Online], Accessed on 28/03/2012, [Available at:http://radar.oreilly.com/2006/12/web20-compact-definition-tryi.html]

Paciello, M. (2000). 'Web Accessibility for People with Disabilities: CMP Books,'

Smillie, D. (2001). 'Access for All,' [Online], Accessed on 9/05/2004, [Available at:http://www.ja.net/conferences/JUSW/2 001/D.Smillie.pdf]

staff, Ukoin \& Jisc Techdis. (2011). Holistic Approaches to Web Accessibility. [Online], Accessed on 03/04/2012, [Available at:http://www.scribd.com/doc/47584551

/Holistic-Approaches-to-Accessibility-

Briefing-DRAFT]

W3C. (2005). User Agent Accessibility Guidelines (UAAG) Overview. [Online], Accessed on 15/05/2008, [Available at:http://www.w3.org/WAI/intro/uaag]

W3C. (2011a). Authoring Tool Accessibility Guidelines (ATAG) 2.0. [Online], Accessed on 31/03/2012, [Available at:http://www.w3.org/TR/ATAG20/]

W3C. (2011b). Developer Guide for Evaluation and Report Language (EARL) 1.0. [Online], Accessed on 31/03/2012, [Available at:http://www.w3.org/TR/EARL10Guide/\#about]

W3C. (2011c). WAI-ARIA Overview. [Online], Accessed on 31/03/2012, [Available at:http://www.w3.org/WAI/intro/aria]

W3C. (2011d). Web Content Accessibility Guidelines (WCAG) Overview. [Online], Accessed on 31/03/2012, [Available at:http://www.w3.org/WAI/intro/wcag]

Web2Access.org.uk. (2012). Disabilities and Tests. [Online], Accessed on 31/03/2012, [Available at:http://www.web2access.org.uk/disabilit y]

www.webaim.org. (2012). Accessibility of AJAX Applications. [Online], Accessed on 06/12/2012, [Available at:http://webaim.org/techniques/ajax/]

www.webcredible.co.uk. (2011). WCAG 2.0: The New W3C Accessibility Guidelines Evaluated. [Online], Accessed on 04/04/2012, [Available at:http://www.webcredible.co.uk/userfriendly-resources/webaccessibility/wcag-guidelines-20.shtml] 